University of Nebraska - Lincoln

DigitalCommons@University of Nebraska - Lincoln

USDA National Wildlife Research Center - Staff Publications
U.S. Department of Agriculture: Animal and Plant Health Inspection Service

April 1998

\title{
COMPARATIVE DEVELOPMENTAL TOXICITY OF PLANAR POLYCHLORINATED BIPHENYL CONGENERS IN CHICKENS, AMERICAN KESTRELS, AND COMMON TERNS
}

\author{
David J. Hoffman \\ Patuxent Wildlife Research Center, U.S. Geological Survey \\ Mark J. Melancon \\ Patuxent Wildlife Research Center, U.S. Geological Survey \\ Patrice N. Klein \\ Patuxent Wildlife Research Center, U.S. Geological Survey \\ John D. Eisemann \\ Patuxent Wildlife Research Center, U.S. Geological Survey, John.D.Eisemann@aphis.usda.gov \\ James W. Spann \\ Patuxent Wildlife Research Center, U.S. Geological Survey
}

Follow this and additional works at: https://digitalcommons.unl.edu/icwdm_usdanwrc

Part of the Environmental Sciences Commons

Hoffman, David J.; Melancon, Mark J.; Klein, Patrice N.; Eisemann, John D.; and Spann, James W., "COMPARATIVE DEVELOPMENTAL TOXICITY OF PLANAR POLYCHLORINATED BIPHENYL CONGENERS IN CHICKENS, AMERICAN KESTRELS, AND COMMON TERNS" (1998). USDA National Wildlife Research Center - Staff Publications. 536.

https://digitalcommons.unl.edu/icwdm_usdanwrc/536

This Article is brought to you for free and open access by the U.S. Department of Agriculture: Animal and Plant Health Inspection Service at DigitalCommons@University of Nebraska - Lincoln. It has been accepted for inclusion in USDA National Wildlife Research Center - Staff Publications by an authorized administrator of DigitalCommons@University of Nebraska - Lincoln. 


\title{
COMPARATIVE DEVELOPMENTAL TOXICITY OF PLANAR POLYCHLORINATED BIPHENYL CONGENERS IN CHICKENS, AMERICAN KESTRELS, AND COMMON TERNS
}

\author{
David J. Hoffman,* Mark J. Melancon, Patrice N. Klein, John D. Eisemann, and James W. Spann \\ Patuxent Wildlife Research Center, U.S. Geological Survey, 12011 Beech Forest Drive, Laurel, Maryland 20708-4041
}

(Received 19 March 1997; Accepted 18 August 1997)

\begin{abstract}
The effects of polychlorinated biphenyl (PCB) congeners, PCB 126 (3,3',4,4',5-pentaCB) and PCB 77 (3,3'4,4'-tetraCB), were examined in chicken (Gallus gallus), American kestrel (Falco sparverius), and common tern (Sterna hirundo) embryos through hatching, following air cell injections on day 4. PCB 126 caused malformations and edema in chickens starting at $0.3 \mathrm{ppb}$, in kestrels at 2.3 to $23 \mathrm{ppb}$, but in terns only at levels affecting hatching success ( $44 \mathrm{ppb}$ ). Extent of edema was most severe in chickens and least in terns. Defects of the beak were common in all species but with crossed beak most prevalent in terns. Effects on embryo growth were most apparent for PCB 126 in chickens and kestrels. The approximate 50\% lethal dose (LD50) for PCB 126 in chickens was $0.4 \mathrm{ppb}$, in kestrels was $65 \mathrm{ppb}$, and in terns was $104 \mathrm{ppb}$. The approximate LD50 for PCB 77 in chickens was $2.6 \mathrm{ppb}$ and in kestrels was $316 \mathrm{ppb}$. Induction of cytochrome $\mathrm{P} 450$ associated monooxygenase activity (ethoxyresorufin- $O$-dealkylase activity) by PCB 126 in chick embryo liver was about 800 times more responsive than in tern and at least 1,000 times more responsive than in kestrel. High concentrations of PCB 126 found in bald eagle eggs are nearly 20 -fold higher than the lowest toxic concentration tested in kestrels. Concentrations of PCB 126 causing low-level toxic effects in common tern eggs are comparable to highest levels in common terns and Forster's terns in the field, suggesting additional involvement of other compounds in the Great Lakes.
\end{abstract}

Keywords-Planar polychlorinated biphenyls Embryo Chicken Common tern American kestrel

\section{INTRODUCTION}

Polychlorinated biphenyls (PCBs) are persistent and lipophilic environmental contaminants that are ubiquitous throughout the global ecosystem in animal tissues including bird eggs [1-7]. The most acutely toxic PCB congeners, including 3,3',4,4',5-pentaCB (PCB 126), can assume coplanar conformations generally similar to that of 2,3,7,8-tetrachlorodibenzo$p$-dioxin (TCDD). Common toxic responses most widely documented in mammals include thymic atrophy, a wasting syndrome, immunotoxic effects, reproductive impairments, porphyria and related liver damage, and induction of specific isozymes of the cytochrome P450 system [6-10]. Gilbertson et al. [11] and others $[4,12,13]$ have documented and reviewed the history of PCB-related reproductive problems in Great Lakes fish-eating birds and their classification as GLEMEDS, Great Lakes Embryo Mortality, Edema, and Deformities Syndrome.

The persistence and lipophilicity of PCBs permits them to biomagnify readily once entering the aquatic food chain. Therefore, bald eagles (Haliaeetus leucocephalus), other raptors, and fish-eating birds (e.g., terns) may be particularly vulnerable because they are at the top of this food chain. Total PCB concentrations in bald eagles on the Great Lakes have been reported to be as high as $100 \mathrm{ppm}$ (fresh weight) in eggs during the past decade [14], with $42 \mathrm{ppm}$ in brains of nestling eagles where there was decreased reproductive success [15]. Schwartz et al. [16] reported $71 \mathrm{ng} / \mathrm{g}$ of PCB congener 126 in a bald eagle egg containing a deformed embryo. This concentration is over 10-fold higher than the 50\% lethal dose (LD50) in the chicken egg [17] and higher than the LD50 in

* To whom correspondence may be addressed (david_hoffman@usgs.gov). the American kestrel egg [18]. Best et al. [19] and Bowerman et al. [20] have further related nest productivity to PCB concentrations in bald eagle eggs that failed to hatch from the Great Lakes. Poor reproductive success of bald eagles in Maine may also be related to high PCB concentrations where $66 \mathrm{ppm}$ in eggs and $47 \mathrm{ppm}$ in nestling liver has been reported [21]. Combined data of Kubiak et al. [22], Brunstrom et al. [23], Smith et al. [24], and Hoffman et al. [6,18,25] suggests that three PCB congeners (126, 77 and 105) may account for over $90 \%$ of the PCB toxicity in eggs of birds, including Forster's tern, in the Great Lakes.

The utility of egg injection studies for predicting potential embryotoxicity of PCBs and TCDD compares favorably with feeding studies [6]. In instances where the same chemicals have been administered by both methods, egg concentrations and effects are quite similar. Comparative avian egg injection studies with PCB congeners by Brunstrom [26-28] have shown that chickens are more sensitive than turkeys, pheasants, ducks (mallards and goldeneyes), domestic geese, herring gulls, and black-headed gulls. Preliminary studies of ours determined the relative effects on embryo mortality of PCB congeners 126, 77, and 105 in chickens, bobwhite, American kestrels, and common terns [18].

The present study examines the effects of the two most acutely toxic of these three PCB congeners PCB 126 and 3,3'4,4'-tetraCB (PCB 77) on embryonic development and cytochrome P450 induction in chickens, American kestrels, and common terns through hatching.

\section{MATERIALS AND METHODS}

\section{Animals and treatments}

Fertile white leghorn chicken eggs were obtained from Truslow Farms, Chestertown, Maryland, USA, stored refrig- 
erated, and placed in incubators within $2 \mathrm{~d}$ of arrival. American kestrel eggs were collected over a 10-d period from the $\mathrm{Pa}-$ tuxent Wildlife Research Center captive colony and stored refrigerated prior to incubation. Common tern eggs determined to be appropriate stage of incubation by flotation and by subsequent candling were collected from an uncontaminated location near Barren Island in the Chesapeake Bay and immediately placed in an incubator. Eggs were incubated at $38^{\circ} \mathrm{C}$ and $60 \%$ relative humidity. Other eggs collected from this colony were analyzed for total PCB concentration, and mean levels were found to be less than $1.5 \mathrm{ppm}$, wet weight, but specific congeners were not determined (J. French, personal communication).

PCB congeners 77 and 126 were $99+\%$ pure and obtained from AccuStandard Inc., New Haven, Connecticut, USA. Eggs were treated on day 4 (chickens and common terns) or the comparable stage (with respect to limb buds, eye pigmentation, and extraembryonic development) of $6 \mathrm{~d}$ of incubation for American kestrels. The shell surface above the center of each air cell was marked, lightly wiped with an alcohol pad, and then drilled through the shell with a Dremel drill. Congeners were prepared in fresh corn oil and injected at various concentrations at $1 \mu \mathrm{l}$ per $\mathrm{g}$ of egg weight. Concentrations of congeners were selected in part on the basis of initial range finders and studies of others [26-28]. For PCB 126 these included 0.3 through $3.2 \mathrm{ng} / \mathrm{g}$ in chickens, 0.23 through $233 \mathrm{ng} / \mathrm{g}$ in American kestrels, and 44 through $434 \mathrm{ng} / \mathrm{g}$ in common terns. For PCB 77 these included 0.12 through $12 \mathrm{ng} / \mathrm{g}$ in chickens, and 100 through $1,000 \mathrm{ng} / \mathrm{g}$ in American kestrels. Controls received the same volume of corn oil alone. Eggs were sealed, candled weekly, and dead embryos examined for malformations.

\section{Morphological measurements}

Hatchlings were euthanized by $\mathrm{CO}_{2}$ inhalation, examined for malformations, and weights recorded with and without excision of the remaining yolk sac. The liver, kidney, thyroid, thymus, and bursa were examined and removed. Livers were frozen at $-80^{\circ} \mathrm{C}$ for subsequent biochemical measurements. Portions of all above organs were placed in $10 \%$ neutral buffered formalin for histological processing (hematoxylin and eosin staining at American Histolabs, Rockville, MD, USA) and examination by light microscopy. Carcasses were cleared and stained with alizarin red-S for skeletal examination according to the procedure of Karnofsky [29]. Skeletons were examined for malformations, and the humerus and radius-ulna of the right wing as well as the femur and tibiotarsus of the right leg were measured.

\section{Hepatic cytochrome P450 measurement}

Portions of liver were homogenized $(1: 4 \mathrm{w} / \mathrm{v})$ in ice-cold $1.15 \% \mathrm{KCl}$ in $0.01 \mathrm{M} \mathrm{Na} / \mathrm{K}$ phosphate buffer $(\mathrm{pH} 7.4)$. The homogenate was centrifuged at $9,000 \mathrm{~g}$ for $20 \mathrm{~min}$ at $4^{\circ} \mathrm{C}$, and the resulting supernatant was centrifuged at $100,000 \mathrm{~g}$ for 60 min. The resulting microsome pellet was resuspended in 0.05 $\mathrm{M} \mathrm{Na} / \mathrm{K}$ phosphate buffer ( $\mathrm{pH}$ 7.6) containing $0.001 \mathrm{M}$ disodium ethylenediamine tetraacetate at $2 \mathrm{ml} / \mathrm{g}$ of portion weight. Protein concentration was determined by the method of Lowry et al. [30]. Monooxygenase activity, as ethoxyresorufin- $O$-dealkylase (EROD), was assayed [31-34]. Assays were adapted to a fluorescence microwell plate scanner and run in a total volume of $0.26 \mathrm{ml}$ at $37^{\circ} \mathrm{C}$ [35]. The assay utilized $1.25 \mu \mathrm{M}$ substrate, $0.125 \mathrm{mM} \mathrm{NADPH}$, and 12 to $20 \mu \mathrm{g}$ of microsomal protein brought to volume with $66 \mathrm{mM}$ Tris buffer, $\mathrm{pH}$ 7.4. Fluorescence units over time were converted to product with the use of a standard curve, and monooxygenase activities were calculated as pmol product per min per mg microsomal protein.

\section{Measurements of oxidative stress}

Portions of the liver were minced and homogenized (1:10 $\mathrm{w} / \mathrm{v}$ ) in ice-cold $1.15 \% \mathrm{KCl}-0.01 \mathrm{M} \mathrm{Na} / \mathrm{K}$-phosphate buffer (pH 7.4). Reduced glutathione (GSH) and the total sulfhydryl concentration (total $\mathrm{SH}$ ) were measured and protein-bound sulfhydryl (PBSH) derived from the difference between these [36,37].

Thiobarbituric acid reactive substances (TBARS) were measured as an estimate of hepatic lipid peroxidation using the method described by Aust [38]. Standard curves were generated for the assay using malondialdehyde tetraethyl acetal.

\section{Statistical analysis}

Survival, hatching success, incidence of malformations, and edema were statistically compared using contingency table analysis. Approximate LD50s were derived by probit analysis when there were three or more dose concentrations in which the percent mortality fell between 10 and 90 for at least two doses. The binomial test was used to derive approximate LD50s for other groups. Weights of hatchlings, crown-rump lengths, liver weights, skeletal lengths, and all biochemical measurements were compared among treatment groups using one-way analysis of variance $(p \leq 0.05)$. Significant differences from the control group were quantified with Dunnett's multiple comparison test $(p \leq 0.05)$.

\section{RESULTS}

\section{Effects of PCB 126}

Chickens. At 3.2 ppb, PCB 126 caused 90\% mortality in chicken embryos within 1 week of treatment, $60 \%$ mortality for the $0.5 \mathrm{ppb}$ group, $3 \%$ for the $0.3 \mathrm{ppb}$ group, and none for corn oil controls (Table 1). Within 2 weeks of treatment, mortality increased to $83 \%$ with $0.5 \mathrm{ppb}$ and to $97 \%$ with $3.2 \mathrm{ppb}$ compared to $3 \%$ for corn oil controls and $7 \%$ for $0.3 \mathrm{ppb}$. With $0.3 \mathrm{ppb}$, additional mortality occurred near the time of hatching, resulting in $77 \%$ hatching success in contrast to no hatching for the other PCB 126 groups and 93\% for controls. The percentage of embryos that succeeded in pipping was generally similar to the percentage that hatched. The approximate LD50 (binomial test) for PCB 126 in chickens, based upon hatching success, was $0.4 \mathrm{ppb}(1.2 \mathrm{nmol} / \mathrm{kg})$. The lowest dose $(0.3 \mathrm{ppb})$ resulted in a significant percentage of embryos and hatchlings with malformations. Higher doses resulted in malformations, but a smaller percentage, probably due to preclusion by early mortality. Most frequent malformations were of the beak, including unequal length of upper and lower portions, and crossed beak. Other malformations are described in Table 1 and Figure 1. Subcutaneous edema appeared to be dose-related, with a significant incidence of 20 to $30 \%$ in the two highest dose groups in contrast to only $3 \%$ in controls. The severity of the edema was greater in chickens than in the other two species. When the incidence of malformations and edema was combined, the combined effect was significant at all dose levels. Other effects included induction of hepatic cytochrome $\mathrm{P} 450$ and alterations in hepatic thiols in hatchlings. The lowest dose level resulted in a significant induction of nearly 17 -fold in microsomal EROD relative to controls. Sig- 
Table 1. Effects of PCB congener 126 on chicken embryos through hatching

\begin{tabular}{|c|c|c|c|c|c|}
\hline Dose (ng/g) & 0 & 0.3 & 0.5 & 1 & 3.2 \\
\hline$N$ & 30 & 30 & 30 & 30 & 30 \\
\hline \multicolumn{6}{|l|}{ Survival (\%) } \\
\hline Days $4-11$ & 100 & 97 & $40^{\mathrm{a}}$ & $30^{\mathrm{a}}$ & $10^{\mathrm{a}}$ \\
\hline Days $11-18$ & 97 & 93 & $17^{\mathrm{a}}$ & $7^{\mathrm{a}}$ & $3^{\mathrm{a}}$ \\
\hline Hatching success $(\%)$ & 93 & 77 & $0^{\mathrm{a}}$ & $0^{\mathrm{a}}$ & $0^{\mathrm{a}}$ \\
\hline Pipped or hatched $(\%)$ & 93 & 80 & $0^{\mathrm{a}}$ & $0^{\mathrm{a}}$ & $0^{\mathrm{a}}$ \\
\hline Hatch weight without yolk sac (g) & $35.2 \pm 2.5$ & $33.2 \pm 2.6^{\mathrm{a}}$ & - & - & - \\
\hline Liver weight $(\mathrm{mg})$ & $879 \pm 144$ & $910 \pm 106$ & - & - & - \\
\hline \multicolumn{6}{|l|}{ Bone lengths } \\
\hline Crown-rump length $(\mathrm{mm})$ & $89.6 \pm 2.7$ & $90.0 \pm 3.0$ & - & - & - \\
\hline Humerus length (mm) & $11.1 \pm 0.6$ & $11.3 \pm 0.5$ & - & - & - \\
\hline Radius-ulna length (mm) & $11.2 \pm 0.6$ & $11.1 \pm 0.5$ & - & - & - \\
\hline Femur length (mm) & $17.7 \pm 0.7$ & $17.9 \pm 0.7$ & - & - & - \\
\hline Tibiotarsus length (mm) & $24.4 \pm 1.8$ & $24.5 \pm 0.9$ & - & - & - \\
\hline \multicolumn{6}{|l|}{ Malformations and edema } \\
\hline Malformed embryos and hatchlings ${ }^{\mathrm{b}}(\%)$ & 3 & $37^{\mathrm{a}}$ & 13 & $20^{\mathrm{a}}$ & 13 \\
\hline Embryos and hatchlings with edema (\%) & 3 & 7 & 10 & $20^{\mathrm{a}}$ & $30^{\mathrm{a}}$ \\
\hline Malformed or edema (\%) & 6 & $44^{\mathrm{a}}$ & $23^{\mathrm{a}}$ & $40^{\mathrm{a}}$ & $43^{\mathrm{a}}$ \\
\hline \multicolumn{6}{|l|}{ Liver biomchemistry } \\
\hline EROD (pmol $/ \mathrm{min} / \mathrm{mg}$ microsomal protein) & $10.5 \pm 3.2$ & $176.6 \pm 43^{\mathrm{a}}$ & - & - & - \\
\hline $\mathrm{GSH}(\mu \mathrm{mol} / \mathrm{g})$ & $1.3 \pm 0.13$ & $2.2 \pm 0.34^{\mathrm{a}}$ & - & - & - \\
\hline Total SH $(\mu \mathrm{mol} / \mathrm{g})$ & $13.1 \pm 2.1$ & $17.1 \pm 1.5^{\mathrm{a}}$ & - & - & - \\
\hline Protein-bound SH $(\mu \mathrm{mol} / \mathrm{g})$ & $11.8 \pm 2.2$ & $14.9 \pm 1.2^{\mathrm{a}}$ & - & - & - \\
\hline TBARS (nmol/g) & $18.5 \pm 2.4$ & $18.5 \pm 3.3$ & - & - & - \\
\hline
\end{tabular}

${ }^{a}$ Significantly different from controls.

${ }^{\mathrm{b}}$ Malformations in the following categories were observed: beak; incomplete ossification of vertebrae, sesamoid bones, skull; club foot; toes; intertarsal joint; liver; microphthalmia; hydrocephaly, and external yolk sac. In addition varying edema and hemorrhaging were common.

nificant increases in hepatic thiols were also apparent for GSH, total SH, and PBSH.

American kestrels. In American kestrels, hatching success was affected at dose levels of PCB 126 that were 40- to 50fold higher than in chickens (Table 2). Unlike chickens, there was relatively little effect on survival within the first 2 weeks following treatment. Even the highest dose administered, 233 ppb, resulted in only $17 \%$ mortality within the first 2 weeks following treatment. However, this dose resulted in $71 \%$ mortality by the time of pipping, in contrast to $20 \%$ for controls, and $31 \%$ for the 23-ppb group. Hatching success, which was $60 \%$ for controls, did not differ significantly from treatment groups at doses less than $233 \mathrm{ppb}$. The approximate LD50, (probit analysis) for kestrels was $65 \mathrm{ppb}(197 \mathrm{nmol} / \mathrm{kg})$. Hatching weights without the yolk sac were numerically lower in all PCB 126-treated groups, but only significantly different in two groups. Liver weights in hatchlings were significantly lower in all treatment groups in a dose-related manner. Bone lengths were significantly shorter for radius-ulna in the highest dose group, and for the femur in three dose groups including the two highest. Malformations in embryos and hatchlings appeared to occur in a dose-dependent manner, as did the incidence of edema. The incidence of malformations was significant in the highest two dose groups. Most frequent malformations included external yolk sac in hatchlings and shorter lower beak. Other defects are described in Table 2. Subcutaneous edema appeared to increase with dose and was significant at the two highest dose levels. The incidence of malformed embryos or edema was significant in all but the lowest dose group. The highest dose level resulted in significant induction in hepatic microsomal EROD of nearly 12 -fold relative to controls. Significant increases in hepatic thiols were also apparent for $\mathrm{GSH}$, total $\mathrm{SH}$, and protein bound $\mathrm{SH}$.
Common terns. In common terns all three dose levels of PCB 126 caused significant mortality (27-53\%) over the range of 44 to $434 \mathrm{ppb}$ within 1 week of treatment with no mortality in controls (Table 3). Within 2 weeks of treatment, the most additional mortality occurred in the highest dose group. Greatest mortality through hatching occurred in the two highest dose groups where $47 \%$ and $7 \%$ hatched, in contrast to $93 \%$ of the controls and $60 \%$ of the low-dosed group. The LD50 (probit analysis) for PCB 126 in common terns, based upon hatching success, was approximately $104 \mathrm{ppb}$ (351 nmol/kg). Differences in hatching weight and bone lengths were not apparent, but malformations increased with increasing dose and the incidence was significant in the two highest dose groups. Most frequent malformations were crossed bills and unequal upper and lower bill lengths. Other deformities are described in Table 3 . The lowest dose level resulted in a significant 2-fold induction in hepatic microsomal EROD relative to controls, and the two highest doses resulted in approximately 17- and 20fold inductions.

\section{$P C B 77$}

Chickens. At 0.12 and $1.2 \mathrm{ppb}$, PCB 77 did not significantly affect survival or hatching (93\% and $83 \%$ ) compared to $93 \%$ for controls (Table 4). At $6 \mathrm{ppb}$ and at $12 \mathrm{ppb}$, there was significant mortality (33\%) within 2 weeks of treatment. Additional mortality occurred near the time of hatching, with hatching success of only $13 \%$ for $6 \mathrm{ppb}$ and none for $12 \mathrm{ppb}$ (Table 1). The percentage of embryos that pipped was generally similar to the percentage that hatched except in the 6ppb group where $20 \%$ pipped. The LD50 (probit analysis) for PCB 77 in chickens, based upon hatching success, was approximately $2.6 \mathrm{ppb}(8.8 \mathrm{nmol} / \mathrm{kg})$. PCB 77 was less teratogenic than PCB 126. Only the highest dose resulted in a sig- 
a
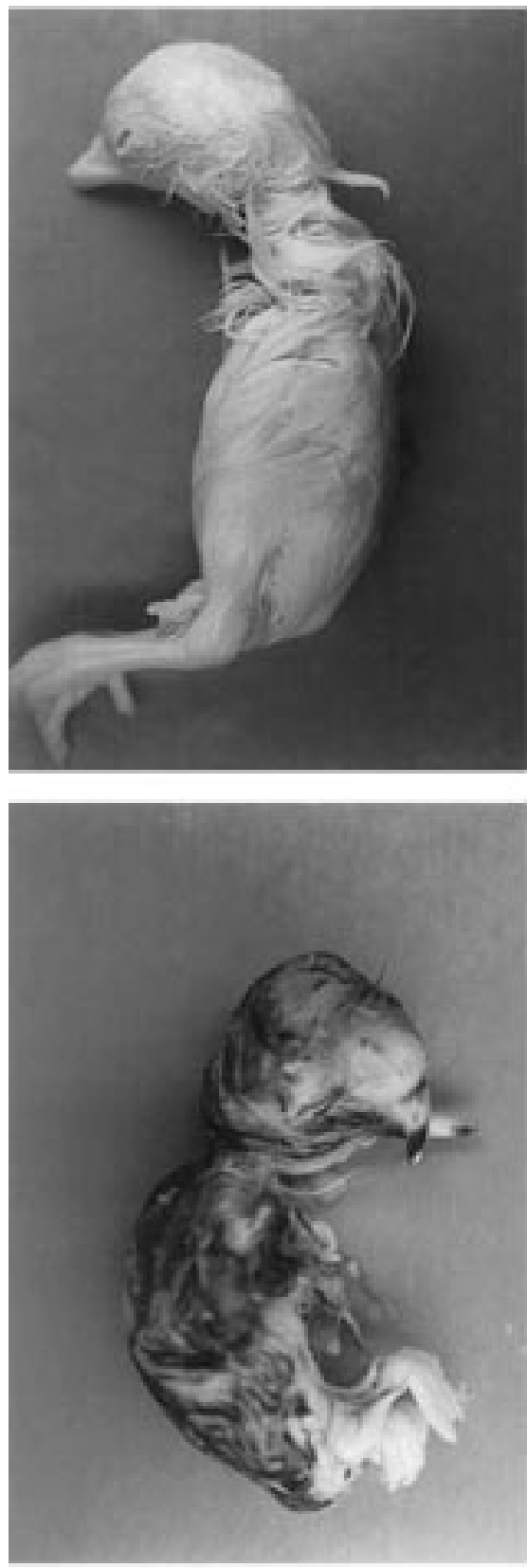

a b
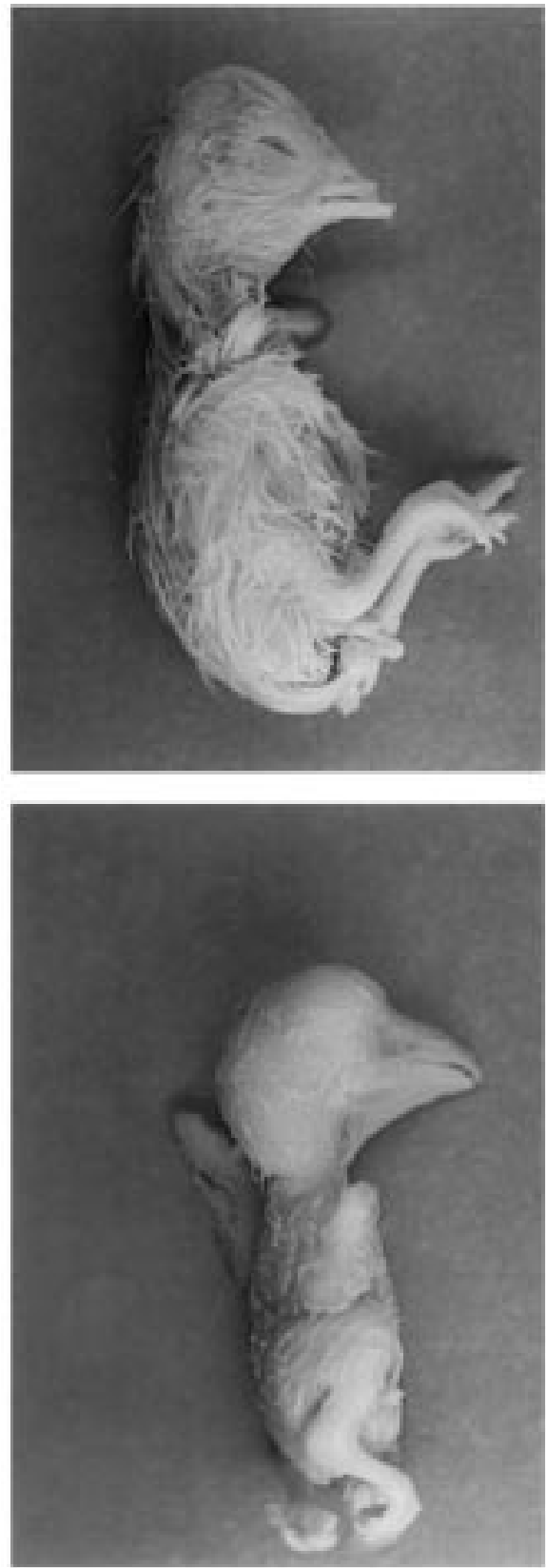

b
C
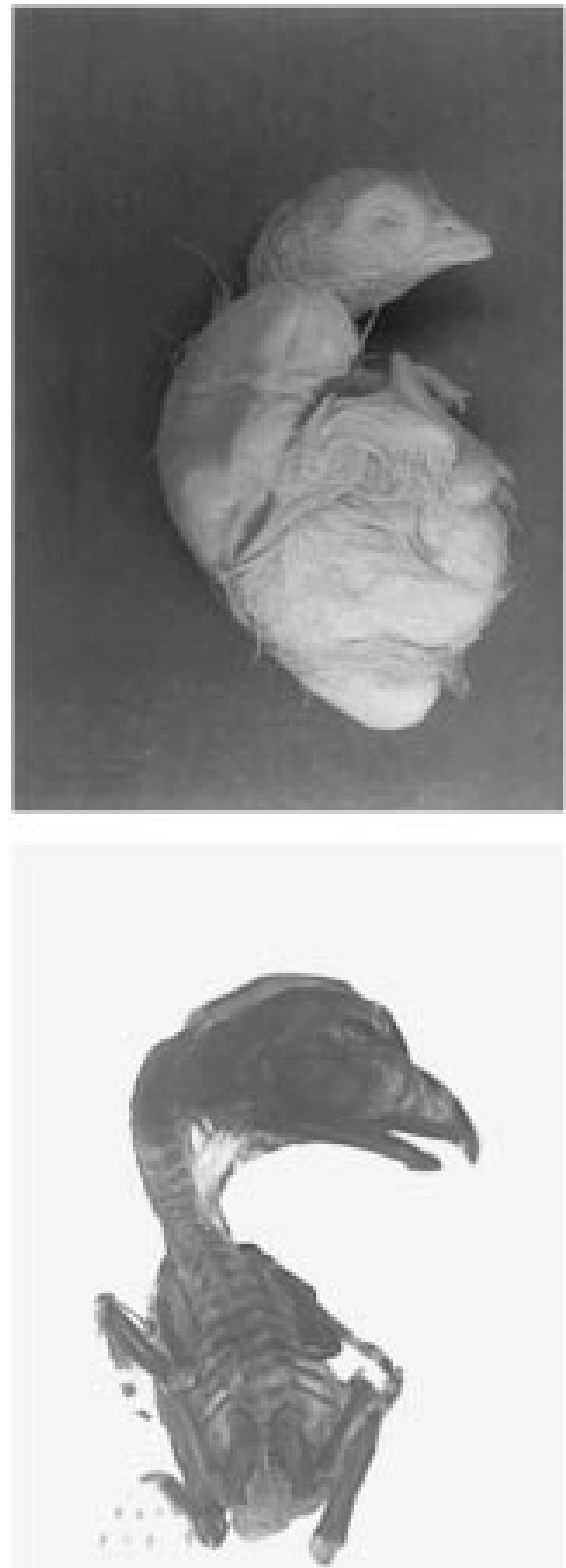

C

Fig. 1. Malformations and edema observed at or near the time of hatching. Top row (left to right): (a) normal control chicken; (b) chicken with beak defect and hydrocephaly, PCB 126 at $0.3 \mathrm{ng} / \mathrm{g}$; and (c) chicken with severe subcutaneous edema. Bottom row (left to right): (a) common tern with crossed bill and hydrocephaly, PCB 126 at $240 \mathrm{ng} / \mathrm{g}$; (b) American kestrel with anophthalmia and microphthalmia, beak defect, and edema, PCB 77 at $100 \mathrm{ng} / \mathrm{g}$; and (c) American kestrel skeleton with incomplete ossification of sacral/caudal vertebrae and beak defect.

nificant incidence of malformations that included in greatest frequency unequal upper and lower beak lengths and twisted toes. Other malformations are described in Table 4. Subcutaneous edema appeared to be dose-related, being significant and highly prevalent in the two highest dose groups. The dose level of $1.2 \mathrm{ppb}$ resulted in a significant fourfold induction of hepatic microsomal EROD relative to controls. Significant increases in hepatic thiols were also apparent for GSH, total SH and PBSH at nearly all dose levels.

American kestrels. In American kestrels, dose levels of
PCB 77 that were at least 30- to 40-fold higher than in chickens, were required to affect hatching success (Table 5). Both doses administered, 100 and $1,000 \mathrm{ppb}$, resulted in only 23 to $31 \%$ mortality during the first 2 weeks following treatment. However, these doses resulted in 62 to $65 \%$ mortality by the time of pipping in contrast to $27 \%$ for controls. Hatching success for both treatment groups was $38 \%$ and $27 \%$ and differed significantly from controls (65\% hatching success). The approximate LD50 (binomial test) for kestrels for PCB 77, based upon hatching success, was $316 \mathrm{ppb}(1,070 \mathrm{nmol} / \mathrm{kg})$. Humerus 
Table 2. Effects of PCB congener 126 on American kestrel embryos through hatching

\begin{tabular}{|c|c|c|c|c|c|}
\hline Dose (ng/g) & 0 & 0.23 & 2.3 & 23 & 233 \\
\hline$N$ & 25 & 25 & 26 & 26 & 24 \\
\hline \multicolumn{6}{|l|}{ Survival (\%) } \\
\hline Days 6-13 & 100 & 96 & 100 & 100 & 100 \\
\hline Days $13-20$ & 100 & 96 & 100 & 100 & 83 \\
\hline Hatching success $(\%)$ & 60 & 56 & 54 & 46 & $13^{\mathrm{a}}$ \\
\hline Pipped or hatched (\%) & 80 & 72 & 84 & 69 & $29^{\mathrm{a}}$ \\
\hline Hatch weight without yolk sac (g) & $9.8 \pm 0.8$ & $8.9 \pm 1.1^{\mathrm{a}}$ & $9.3 \pm 1.0$ & $8.8 \pm 0.6^{\mathrm{a}}$ & $9.0 \pm 0.9$ \\
\hline Liver weight (mg) & $311 \pm 45$ & $267 \pm 37^{a}$ & $262 \pm 43^{a}$ & $254 \pm 27^{a}$ & $231 \pm 30^{\mathrm{a}}$ \\
\hline \multicolumn{6}{|l|}{ Bone lengths } \\
\hline Crown-rump length (mm) & $59.2 \pm 1.6$ & $58.4 \pm 1.7$ & $58.8 \pm 2.2$ & $57.9 \pm 1.4$ & $58.0 \pm 1.0$ \\
\hline Humerus length $(\mathrm{mm})$ & $6.7 \pm 0.3$ & $6.6 \pm 0.4$ & $6.7 \pm 0.3$ & $6.5 \pm 0.3$ & $6.3 \pm 0.3$ \\
\hline Radius-ulna length (mm) & $7.2 \pm 0.3$ & $7.0 \pm 0.3$ & $7.0 \pm 0.3$ & $6.9 \pm 0.3$ & $6.7 \pm 0.4^{\mathrm{a}}$ \\
\hline Femur length (mm) & $8.7 \pm 0.4$ & $8.3 \pm 0.4^{\mathrm{a}}$ & $8.6 \pm 0.3$ & $8.3 \pm 0.4^{\mathrm{a}}$ & $7.9 \pm 0.1^{\mathrm{a}}$ \\
\hline Tibiotarsus length (mm) & $10.4 \pm 1.0$ & $10.5 \pm 0.5$ & $10.6 \pm 0.5$ & $10.5 \pm 0.4$ & $10.3 \pm 0.1$ \\
\hline \multicolumn{6}{|l|}{ Malformations and edema } \\
\hline Malformed embryos and hatchlings ${ }^{\mathrm{b}}(\%)$ & 4 & 16 & 19 & $23^{\mathrm{a}}$ & $29^{\mathrm{a}}$ \\
\hline Embryos and hatchlings with edema (\%) & 8 & 12 & 23 & $35^{\mathrm{a}}$ & $38^{\mathrm{a}}$ \\
\hline Malformed or edema $(\%)$ & 12 & 28 & $42^{\mathrm{a}}$ & $58^{\mathrm{a}}$ & $67^{\mathrm{a}}$ \\
\hline \multicolumn{6}{|l|}{ Liver biochemistry } \\
\hline EROD (pmol/min/mg microsomal protein) & $5.9 \pm 1.8$ & $5.7 \pm 2.5$ & $6.9 \pm 3.9$ & $9.3 \pm 5.2$ & $68 \pm 50^{\mathrm{a}}$ \\
\hline $\mathrm{GSH}(\mu \mathrm{mol} / \mathrm{g})$ & $2.9 \pm 0.8$ & $3.4 \pm 1.1$ & $3.4 \pm 1.0$ & $3.0 \pm 0.7$ & $(2.6)$ \\
\hline Total SH $(\mu \mathrm{mol} / \mathrm{g})$ & $17.7 \pm 2.6$ & $17.3 \pm 2.7$ & $18.7 \pm 2.9$ & $18.4 \pm 2.5$ & $(13.8)$ \\
\hline Protein-bound SH $(\mu \mathrm{mol} / \mathrm{g})$ & $14.8 \pm 2.0$ & $13.9 \pm 1.8$ & $15.3 \pm 2.5$ & $15.4 \pm 1.9$ & $(11.1)$ \\
\hline TBARS $(\mathrm{nmol} / \mathrm{g})$ & $18.6 \pm 2.5$ & $20.0 \pm 4.0$ & $19.4 \pm 3.3$ & $18.5 \pm 1.3$ & $(22.1)$ \\
\hline
\end{tabular}

a Significantly different from controls.

${ }^{\mathrm{b}}$ Malformations in the following categories were observed: beak; liver/gall bladder; and external yolk sac. In addition varying edema was present.

length in hatchlings was significantly shorter in the highest dose group relative to controls. Malformations in embryos and hatchlings appeared to occur in a dose-dependent manner. The incidence of malformations was significant in the highest dose group. Most frequent malformations included shorter lower beak and external yolk sac in hatchlings. Other defects are described in Table 5. Subcutaneous edema appeared to increase with treatment but did not significantly differ from controls.

Table 3. Effects of PCB congener 126 on common tern embryos through hatching

\begin{tabular}{|c|c|c|c|c|}
\hline Dose (ng/g) & 0 & 44 & 240 & 434 \\
\hline$N$ & 15 & 15 & 15 & 15 \\
\hline \multicolumn{5}{|l|}{ Survival (\%) } \\
\hline Days $4-11$ & 100 & $73^{\mathrm{a}}$ & $73^{\mathrm{a}}$ & $47^{\mathrm{a}}$ \\
\hline Days $11-18$ & 100 & $67^{\mathrm{a}}$ & $67^{\mathrm{a}}$ & $27^{\mathrm{a}}$ \\
\hline Hatching success $(\%)$ & 93 & $60^{\mathrm{a}}$ & $47^{\mathrm{a}}$ & $7^{\mathrm{a}}$ \\
\hline Pipped or hatched (\%) & 93 & $60^{\mathrm{a}}$ & $47^{\mathrm{a}}$ & $7^{\mathrm{a}}$ \\
\hline Hatch weight without yolk sac (g) & $12.8 \pm 1.0$ & $11.8 \pm 1.6$ & $12.7 \pm 1.7$ & (12.6) \\
\hline Liver weight (mg) & $485 \pm 79$ & $403 \pm 56^{\mathrm{a}}$ & $453 \pm 78$ & $(420)$ \\
\hline \multicolumn{5}{|l|}{ Bone lengths } \\
\hline Crown-rump length (mm) & $70.6 \pm 2.1$ & $70.4 \pm 3.7$ & $71.0 \pm 4.7$ & $(69.0)$ \\
\hline Humerus length (mm) & $8.0 \pm 0.4$ & $7.6 \pm 0.6$ & $8.1 \pm 0.6$ & $(8.2)$ \\
\hline Radius-ulna length (mm) & $9.4 \pm 0.5$ & $9.1 \pm 0.6$ & $9.2 \pm 0.6$ & $(8.8)$ \\
\hline Femur length $(\mathrm{mm})$ & $9.6 \pm 0.6$ & $9.1 \pm 0.4$ & $9.6 \pm 0.5$ & $(9.3)$ \\
\hline Tibiotarsus length (mm) & $16.3 \pm 0.8$ & $16.1 \pm 1.2$ & $16.4 \pm 1.1$ & $(15.5)$ \\
\hline \multicolumn{5}{|l|}{ Malformations and edema } \\
\hline Malformed embryos and hatchlings ${ }^{\mathrm{b}}(\%)$ & 0 & 13 & $27^{\mathrm{a}}$ & $33^{\mathrm{a}}$ \\
\hline Embryos and hatchlings with edema (\%) & 0 & 0 & 7 & 7 \\
\hline Malformed or edema $(\%)$ & 0 & 13 & $34^{\mathrm{a}}$ & $40^{\mathrm{a}}$ \\
\hline \multicolumn{5}{|l|}{ Liver biochemistry } \\
\hline EROD (pmol/min/mg microsomal protein) & $11.4 \pm 3.1$ & $21.8 \pm 5.9^{\mathrm{a}}$ & $192.5 \pm 18^{\mathrm{a}}$ & $(231)$ \\
\hline $\mathrm{GSH}(\mu \mathrm{mol} / \mathrm{g})$ & $3.6 \pm 1.3$ & $3.6 \pm 1.6$ & $3.9 \pm 0.8$ & $(3.5)$ \\
\hline Total SH $(\mu \mathrm{mol} / \mathrm{g})$ & $17.2 \pm 1.8$ & $17.1 \pm 3.0$ & $17.7 \pm 1.8$ & $(16.9)$ \\
\hline Protein-bound SH $(\mu \mathrm{mol} / \mathrm{g})$ & $13.6 \pm 1.3$ & $13.5 \pm 1.7$ & $13.8 \pm 1.3$ & (13.4) \\
\hline TBARS $(\mathrm{nmol} / \mathrm{g})$ & $34.5 \pm 27.6$ & $32.5 \pm 32.9$ & $19.5 \pm 3.4$ & $(15.5)$ \\
\hline
\end{tabular}

${ }^{a}$ Significantly different from controls.

${ }^{\mathrm{b}}$ Malformations in the following categories were observed: beak; incomplete ossification of vertebrae, sesamoid bones; club foot; liver; hydrocephaly; and external yolk sac. 
Table 4. Effects of PCB congener 77 on chicken embryos through hatching

\begin{tabular}{|c|c|c|c|c|c|}
\hline Dose (ng/g) & 0 & 0.12 & 1.2 & 6 & 12 \\
\hline$N$ & 30 & 30 & 30 & 30 & 30 \\
\hline \multicolumn{6}{|l|}{ Survival $(\%)$} \\
\hline Days $4-11$ & 100 & 100 & 93 & 87 & 90 \\
\hline Days $11-18$ & 100 & 100 & 90 & $77^{\mathrm{a}}$ & $77^{\mathrm{a}}$ \\
\hline Hatching success $(\%)$ & 93 & 93 & 83 & $13^{\mathrm{a}}$ & $0^{\mathrm{a}}$ \\
\hline Pipped or hatched $(\%)$ & 97 & 93 & 83 & $20^{\mathrm{a}}$ & $0^{\mathrm{a}}$ \\
\hline Hatch weight without yolk sac $(\mathrm{g})$ & $35.2 \pm 2.5$ & $34.1 \pm 2.5$ & $33.4 \pm 3.2$ & $34.9 \pm 2.7$ & - \\
\hline Liver weight $(\mathrm{mg})$ & $879 \pm 144$ & $922 \pm 115$ & $827 \pm 67$ & $730 \pm 52^{\mathrm{a}}$ & - \\
\hline \multicolumn{6}{|l|}{ Bone lengths } \\
\hline Crown-rump length (mm) & $89.6 \pm 2.7$ & $89.5 \pm 3.1$ & $90.2 \pm 3.0$ & $86.9 \pm 0.9$ & - \\
\hline Humerus length $(\mathrm{mm})$ & $11.1 \pm 0.6$ & $11.0 \pm 0.5$ & $10.9 \pm 0.5$ & $11.4 \pm 0.6$ & - \\
\hline Radius-ulna length (mm) & $11.2 \pm 0.6$ & $10.6 \pm 0.6^{\mathrm{a}}$ & $11.2 \pm 0.6$ & $11.9 \pm 0.5$ & - \\
\hline Femur length (mm) & $17.8 \pm 0.7$ & $17.8 \pm 0.5$ & $17.9 \pm 0.7$ & $18.4 \pm 0.8$ & - \\
\hline Tibiotarsus length (mm) & $24.4 \pm 1.8$ & $24.7 \pm 0.7$ & $23.9 \pm 1.9$ & $24.9 \pm 0.7$ & - \\
\hline \multicolumn{6}{|l|}{ Malformations and edema } \\
\hline Malformed embryos and hatchlings ${ }^{\mathrm{b}}(\%)$ & 3 & 7 & 13 & 3 & $23^{\mathrm{a}}$ \\
\hline Embryos and hatchlings with edema (\%) & 3 & 7 & 3 & $60^{\mathrm{a}}$ & $33^{\mathrm{a}}$ \\
\hline Malformed or edema (\%) & 6 & 14 & 17 & $63^{\mathrm{a}}$ & $56^{\mathrm{a}}$ \\
\hline \multicolumn{6}{|l|}{ Liver biochemistry } \\
\hline EROD $(\mathrm{pmol} / \mathrm{min} / \mathrm{mg}$ microsomal protein) & $9.5 \pm 2.8$ & $15.8 \pm 4.3$ & $42.0 \pm 22.5^{\mathrm{a}}$ & - & - \\
\hline $\mathrm{GSH}(\mu \mathrm{mol} / \mathrm{g})$ & $1.3 \pm 0.13$ & $1.8 \pm 0.28^{\mathrm{a}}$ & $2.1 \pm 0.25^{\mathrm{a}}$ & $1.7 \pm 0.43$ & - \\
\hline Total SH $(\mu \mathrm{mol} / \mathrm{g})$ & $13.1 \pm 2.1$ & $16.7 \pm 1.3^{\mathrm{a}}$ & $16.2 \pm 0.5^{\mathrm{a}}$ & $15.7 \pm 2.1^{\mathrm{a}}$ & - \\
\hline Protein-bound $\mathrm{SH}(\mu \mathrm{mol} / \mathrm{g})$ & $11.8 \pm 2.2$ & $14.8 \pm 1.3^{\mathrm{a}}$ & $14.0 \pm 0.5^{\mathrm{a}}$ & $14.0 \pm 1.7^{\mathrm{a}}$ & - \\
\hline TBARS $(\mathrm{nmol} / \mathrm{g})$ & $18.5 \pm 2.4$ & $14.8 \pm 3.1^{\mathrm{a}}$ & $15.6 \pm 2.0$ & $13.3 \pm 3.1^{\mathrm{a}}$ & - \\
\hline
\end{tabular}

a Significantly different from controls.

${ }^{\mathrm{b}}$ Malformations in the following categories were observed: beak; toes; intertarsal joint; liver; and hydrocephaly. In addition varying edema and hemorrhaging were common.

However, the combined incidence of malformed or edema was significant in both dose groups. The highest dose level resulted in significant induction in hepatic microsomal EROD of over twofold relative to controls. Numerical but not statistically significant increases in hepatic thiols were apparent for GSH, total $\mathrm{SH}$, and PBSH.

\section{DISCUSSION}

\section{Comparative effects on embryo mortality}

When the effects of planar PCB congeners, PCB 126 and PCB 77, were examined on embryonic survival in chickens (Gallus gallus), American kestrels (Falco sparverius), and common terns (Sterna hirundo) through hatching following air cell injection, greatest toxicity occurred in chickens with estimated LD50s of approximately $0.4 \mathrm{ppb}$ (PCB 126) and 2.6 ppb (PCB 77). In contrast, we previously reported much lower toxicity in chickens for the less planar congener PCB 105 $\left(2,3,3^{\prime}, 4,4^{\prime}\right.$-pentaCB $)$ and nonplanar PCB $153\left(2,2^{\prime}, 4,4^{\prime}, 5,5^{\prime}\right)$, where LD50s were 3,326 ppb for PCB 105 and greater than $14,000 \mathrm{ppb}$ for PCB $153[6,18]$. Comparison of the toxicity of PCB congeners injected into the yolk sac of chicken eggs ( $4 \mathrm{~d}$ of incubation) by others also revealed greatest acute toxicity for PCB 126 [27]. With air cell injections later in development on day 7 of incubation, LD50s (72 h postinjection) for PCB congeners 126, 77, 169, and 105 were 3.1, 8.6, 170, 2,200 ppb (i.e., 9.4, 29, 480, 6,700 nmol/kg), respectively $[17,23,28]$. However, when injections were administered at an earlier stage of incubation (day 4) via the yolk sac and eggs incubated until day 18 , the above congeners caused even greater embryonic mortality. Congener PCB 126 was approximately fivefold more toxic than PCB 77, in close agreement with our findings. The difference between our present results, especially for PCB 126, and the air cell injection studies of Brunstrom and Andersson [17] is likely due to two factors: (1) day 4 of incubation was used, an earlier and more sensitive stage of embryonic development; and (2) eggs were permitted to hatch, also a critical stage for survival, in contrast to Brunstrom and Andersson [17] who used day 7 embryos for dosing and recorded LD50s only 72 h later. Indeed, when Brunstrom and Danerud [39] injected PCB 77 into the yolk sac of chicken eggs at $4 \mathrm{~d}$ of incubation, and permitted the eggs to hatch, they reported that $4 \mathrm{ppb}$ decreased hatching success by $40 \%$ in very close agreement with our present findings and those of Hoffman et al. [6,18]. More recently Powell et al. [40] reported an approximate LD50 of $0.6 \mathrm{ppb}$ for PCB 126 in chicken embryos, which was similar to our findings. They injected into the yolk prior to incubation using an emulsion of lecithin as vehicle and made observations through hatching. However, these authors subsequently reported a higher LD50 of $2.3 \mathrm{ppb}$ when a different vehicle (triolein) was used [41]. Rifkind et al. [42] injected chicken eggs (unspecified location of injection) at a much later and less sensitive stage of development ( $10 \mathrm{~d}$ of incubation), using 5 to $1,000 \mathrm{nmol} / \mathrm{egg}$ for each of three PCB congeners including PCB 77. PCB 77 caused dose-related decreases in survival from day 10 through $19 \mathrm{~d}$ of exposure at 100 to $1,000 \mathrm{nmol} / \mathrm{egg}$ (584-5,840 ppb, assuming a 50-g egg constant mass).

In the present study, other species were considerably less sensitive relative to the chicken. The estimated LD50 for PCB 126 through hatching was 65 ppb for American kestrels, and $104 \mathrm{ppb}$ for common terns. The estimated LD50 for PCB 77 was $688 \mathrm{ppb}$ for American kestrels. Hoffman et al. [6,18] previously reported an LD50 of 24 ppb (PCB 126 through hatching) in bobwhite embryos, suggesting a generally greater 
Table 5. Effects of PCB congener 77 on American kestrel embryos through hatching

\begin{tabular}{lccc}
\hline Dose (ng/g) & 0 & 100 & 1,000 \\
\hline$N$ & 26 & 26 & 26 \\
Survival (\%) & & & \\
Days 6-13 & 100 & 85 & 88 \\
Days 13-20 & 100 & $77^{\mathrm{a}}$ & $69^{\mathrm{a}}$ \\
Hatching success (\%) & 65 & $38^{\mathrm{a}}$ & $27^{\mathrm{a}}$ \\
Pipped or hatched (\%) & 73 & $38^{\mathrm{a}}$ & $35^{\mathrm{a}}$ \\
Hatch weight without yolk sac (g) & $9.3 \pm 0.9$ & $9.7 \pm 0.9$ & $9.0 \pm 1.3$ \\
Liver weight (mg) & $276 \pm 39$ & $236 \pm 65$ & $265 \pm 44$ \\
Bone lengths & & & \\
Crown-rump length (mm) & $56.2 \pm 2.3$ & $53.6 \pm 5.3$ & $54.8 \pm 4.1$ \\
Humerus length (mm) & $6.8 \pm 0.2$ & $6.6 \pm 0.4$ & $6.4 \pm 0.4^{\mathrm{a}}$ \\
Radius-ulna length (mm) & $7.1 \pm 0.2$ & $6.9 \pm 0.3$ & $6.8 \pm 0.4$ \\
Femur length (mm) & $8.7 \pm 0.3$ & $8.4 \pm 0.6$ & $8.3 \pm 0.6$ \\
Tibiotarsus length (mm) & $10.7 \pm 0.3$ & $10.6 \pm 0.6$ & $10.2 \pm 0.8$ \\
Malformations and edema & & & \\
Malformed embryos and hatchlingsb $(\%)$ & 4 & 19 & $42^{\mathrm{a}}$ \\
Embryos and hatchlings with edema (\%) & 8 & 31 & 27 \\
Malformed or edema (\%) & 12 & $50^{\mathrm{a}}$ & $69^{\mathrm{a}}$ \\
Liver biochemistry & & & \\
EROD (pmol/min/mg microsomal protein) & $5.9 \pm 1.8$ & $8.3 \pm 2.3$ & $14.3 \pm 7.1^{\mathrm{a}}$ \\
GSH ( $\mu$ mol/g) & $1.9 \pm 0.4$ & $2.2 \pm 0.6$ & $3.9 \pm 2.2$ \\
Total SH ( $\mu$ mol/g) & $16.0 \pm 1.1$ & $18.5 \pm 1.0$ & $19.8 \pm 3.4$ \\
Protein-bound SH ( $\mu$ mol/g) & $14.1 \pm 1.0$ & $16.3 \pm 1.2$ & $15.9 \pm 1.5$ \\
TBARS (nmol/g) & $28.3 \pm 4.8$ & $27.8 \pm 1.9$ & $22.1 \pm 6.3$ \\
\hline
\end{tabular}

a Significantly different from controls.

${ }^{\mathrm{b}}$ Malformations in the following categories were observed: beak; incomplete ossification of vertebrae; scoliosis; toes; intertarsal joint; club foot; liver; microphthalmia; and external yolk sac. In addition varying edema and hemorrhaging were common.

sensitivity for gallinaceous birds. Comparative avian egg injection studies by Brunstrom and coworkers have shown that chickens are more sensitive than turkeys (Meleagris gallopavo), pheasants, ducks (mallards and goldeneyes; Bucephala clangula), domestic geese (Anser anser), herring gulls, and black-headed gulls (Larus ridibundus); at a dose of $20 \mathrm{ppb}$ PCB 77, mortality in chicken embryos of 70 to $100 \%$ occurred by $18 \mathrm{~d}$ of incubation with malformations, yet $5,000 \mathrm{ppb}$ to ducks and 1,000 ppb to geese and herring gulls had no effects [26]. These authors also determined gallinaceous species to be more sensitive than other species where 1,000 ppb of PCB 77 in pheasant eggs resulted in complete mortality [43]. In turkeys, 200 to $1,000 \mathrm{ppb}$ caused 17 to $60 \%$ mortality [44]. For PCB 77 and kestrels, comparison of our survival observations at $18 \mathrm{~d}$ of embryonic development to those of Brunstrom and coworkers suggests that kestrels are probably more sensitive than ducks, geese, and herring gulls but less sensitive than pheasants and perhaps comparable to turkeys. This would suggest that bald eagles, if comparable to kestrels, are more sensitive than herring gulls.

\section{Malformations, edema, and growth}

Malformations and edema observed were apparent in all three species studied and were characteristic of those identified in the Great Lakes as GLEMEDS [11]. For PCB 126, edema was most prevalent and severe in chickens but more prevalent in kestrels than common terns. Defects of the beak were the most frequent anomaly in all species studied and included shortened as well as crossed beak, where crossed beak was most prevalent in terns. Others have reported similar edema and anomalies in chickens following in ovo injections of planar
PCBs $[17,40,41]$. The presence of generally similar malformations with edema found in this study have been reported in common, Forster's, and Caspian terns as well as double crested cormorants on the Great Lakes; these included incomplete skeletal ossification and crossed beak [25,45-47]. Beak defects similar to ones reported in kestrels have been reported in bald eagles from the Great Lakes [19,20,48]. Malformations were first apparent at concentrations below those affecting hatching success in chickens and kestrels but first became apparent in terns at levels that affected hatching success, suggesting different thresholds for teratogenesis relative to mortality. PCB 77 produced generally similar defects and edema as PCB 126 in chickens and kestrels.

Differences in embryo growth measured in hatchlings were apparent for PCB 126 in chickens where hatching weights without yolk sacs were lower. Hatching weights without yolk sacs are considered to be a more accurate measure of embryo growth, because when growth is retarded, less yolk is utilized, thus masking the effect when embryos and their yolk are weighed $[49,50]$.

Hatching weights and liver weights in treated kestrels were lower than those of vehicle-treated controls, and lengths of several bones (radius-ulna, femur, and tibiotarsus) were shorter. In the present study, these were not affected by PCB 126 in common terns. However, decreased femur length and hatching weight (without yolk sac) have been associated with PCB exposure in common and Forster's terns in the Great Lakes $[25,45]$.

Differences between laboratory and field studies may be due to the collective effects of multiple PCB congeners found in the field. Effects on growth of PCB 77 relative to effects 
of PCB 126 were somewhat less in chickens and kestrels. Powell et al. [40,41] reported lower hatching weight in chickens with egg injections of PCB 126 and decreased posthatching growth. PCB 77 also decreased posthatching growth as well as relative liver weight. Others have characterized effects on lymphoid development but usually prior to hatching. Nonortho-chlorinated (coplanar) congeners were more potent inhibitors than mono-ortho-chlorinated congeners of lymphoid development in the embryonic bursa [23]. Rifkind et al. [42] reported decreases in survival to be accompanied by decreased thymus weight in surviving embryos. Andersson et al. [51] compared numbers of lymphoid cells in the thymus and in the bursa after chicken eggs were treated with coplanar PCB congeners by air cell injection on day 13 . Here $50 \%$ effective dose (ED50) values (50\% of maximum inhibition) for bursal development were $4 \mu \mathrm{g} / \mathrm{kg}$ (ppb) for PCB 126, 50 for PCB 77, and 300 for PCB 169.

\section{Hepatic cytochrome P450 induction and glutathione}

PCB 126 was a more potent inducer of cytochrome P450 associated monooxygenas activity (EROD) in chick embryo liver than PCBs 77, 105, or 153 [6,18], as was established by Brunstrom [27]. The P450-inducing potencies were consistent with embryolethality in chickens. In keeping with this, the toxic equivalency factors (TEFs) derived from the present study and from Hoffman et al. [6,18] for PCB congeners 126, 77 , and 105 were approximately $0.35,0.06$, and 0.00005 , based upon the chicken egg LD50 of approximately $150 \mathrm{ppt}$ for 2,3,7,8-TCDD [52,53]. In the present study, PCB 126 was also a better inducer than PCB 77 in the kestrel. Baseline EROD activity was lowest in kestrel, with chicken and tern baseline activity being almost twice as great. For responsiveness of hepatic microsomal EROD activity to PCB 126 the order was: chicken $>>>$ common tern $\geq$ kestrel, with chicken being approximately 800 times more responsive than common tern and at least 1,000 times more responsive than kestrel. Bosveld et al. [54] reported up to fourfold induction of hepatic EROD related to a fivefold increase in toxic equivalents (TEQs) (mainly due to non-ortho- and mono-ortho-PCBs) in hatchling common terns from estuarine and coastal colonies in the Netherlands and Belgium compared to a reference colony. Both PCB 126 (as high as $13 \mathrm{ng} / \mathrm{g}$ wet weight) and PCB 77 (as high as $23 \mathrm{ng} / \mathrm{g}$ wet weight) were present in yolk sac samples of the hatchlings, and, under conditions of artificial incubation, hatching time was delayed by several days in eggs containing increased TEQ. Murk et al. [55] reported positive correlations between hepatic EROD activity and thyroid hormone parameters TT4 and FT4, T4-glucuronyltransferase activity, as well as plasma retinol and vitamin A2 levels in hatchling common terns from multiple colonies, differing in degree of polyhalogenated aromatic hydrocarbon pollution.

For PCB 77, EROD responsiveness was also more than 1,000 times greater in chicken than in kestrel. Recently, Kennedy et al. [56] have reported that the relative sensitivity of avian hepatocyte cultures among species to EROD induction by PCB 77 was similar to that for lethality following egg injection. Rifkind et al. [42] reported that the dose-response relationships for lethality and for hepatic P450 induction (aryl hydrocarbon hydroxylase $[\mathrm{AHH}]$ and EROD) activities were dissociated following chicken egg injections (unspecified location) at $10 \mathrm{~d}$ or later of embryonic development, and that the maximal induction levels were not correlated with the extent of lethality.
In the present study, several indications of altered glutathione metabolism were apparent mainly in chickens. These included significant increases in different hepatic thiols (GSH, PBSH, and total thiols) in chicken embryos with PCB 126 and 77. Thiols were not significantly affected in common terns or kestrels by either congener but showed a numerical increase for PCB 77 in kestrels. In the present study, oxidized glutathione was not assessed. However, increased oxidized glutathione was apparent in hatchling wood ducks (Aix sponsa) nesting downstream from a hazardous waste site contaminated with polychlorinated dibenzo- $p$-dioxins and dibenzofurans [57] and in cormorants in Green Bay, Wisconsin, USA, exposed to PCBs in the food chain (D. Hoffman, unpublished data). Rifkind et al. [58] reported a lack of effect on hepatic GSH in chicken eggs (unspecified location of injection) treated at $10 \mathrm{~d}$ of incubation with three PCB congeners including PCB 77. In nestling kestrels, a significant relationship occurred between ratio of GSSG to GSH with dose of PCB 126 and a highly significant relationship between this ratio and concentration of PCB 126 in the liver [59]. This relationship was also found for PCB congener 77 [60]. Other toxicants in other species have resulted in decreased concentrations of reduced thiols during embryonic development in birds and include diquat in mallards [61] and mercury in great blue herons [62].

\section{Ecological risk to eagles and terns}

High concentrations of PCB 126 found in bald eagle eggs $[16,61]$ are within the range of the LD50 (65 ppb) in the present study for American kestrels but are nearly 20-fold higher than the lowest concentration tested in kestrels that caused significant edema and teratogenesis. Potentially harmful concentrations of PCB 126 and PCB 77 have been also reported in eggs of the white-tailed sea eagle (Haliaeetus albicilla) in the Baltic Sea area $[63,64]$.

Egg injection concentrations of PCB 126, causing low-level toxic effects in common tern eggs, are comparable only to very highest levels occurring in Great Lakes common terns and closely related Forster's terns. When Forster's tern eggs from a Green Bay, Wisconsin, colony in the Great Lakes region contained a median concentration of $23 \mathrm{ppm}$ total PCBs and 37 ppt of 2,3,7,8-TCDD (2,175 ppt total median estimated TCDD-equivalents [EQs]), hatching success was only $50 \%$. These hatchlings weighed less, had an increased ratio of liver weight to body weight, shorter femur length, edema, and malformations relative to inland controls. Hepatic P450 activity (AHH) was threefold higher than in controls. Data of Kubiak et al. [22] and Smith et al. [24] suggest that on the basis of relative $\mathrm{AHH}$ induction potencies of individual $\mathrm{PCB}$ congeners as TCDD-EQs, that three congeners, PCB 126, PCB 105, and PCB 77 accounted for over $90 \%$ of the toxicity $(2,175 \mathrm{ppt}$ versus 201 ppt total median estimated TCDD-EQs). Mean total PCB levels for common tern eggs of above $7.5 \mathrm{ppm}$ were associated with decreased hatching success. In Caspian terns, egg concentrations in the 20 to $40 \mathrm{ppm}$ range did not seem to alter productivity possibly due to the larger size and slower metabolism of this species than the other terns, but frequency of deformed embryos was related to PCBs [47,65]. Mora et al. [66] found that plasma concentrations of total PCBs in adult Caspian terns were greatest in Green Bay and Saginaw Bay, where banding studies showed that less birds returned to their natal region, suggesting poorer survival in locations with increasing plasma PCB concentration. 


\section{CONCLUSION}

Planar PCB congeners were considerably more toxic to chicken embryos through hatching (LD50s of $0.4 \mathrm{ppb}$ for PCB 126 and $2.6 \mathrm{ppb}$ for PCB 77) than the less planar congener PCB 105 and the nonplanar PCB 153 (LD50s were 3,326 ppb and greater than $14,000 \mathrm{ppb}$ ) $[5,18]$. The order of embryotoxicity for PCB 126 by species was chickens $>$ kestrels $>$ common terns based upon survival and incidence of malformations and edema, whereas the order for responsiveness of hepatic microsomal EROD activity to PCB 126 was: chicken $>>>$ common tern $\geq$ kestrel. Malformations and edema observed in all three species were characteristic of those identified in the Great Lakes as GLEMEDS. Malformations were first apparent in chickens and kestrels at concentrations below those affecting hatching success but in terns only at levels affecting hatching success, suggesting different thresholds for teratogenesis relative to mortality. High concentrations of PCB 126 found in bald eagle eggs are within the range of the LD50 (65 $\mathrm{ppb}$ ) in the present study for American kestrels but are nearly 20-fold higher than the lowest concentration tested in kestrels that caused significant edema and teratogenesis. Egg injection concentrations of PCB 126 causing low-level toxic effects in common tern eggs are comparable to highest levels occurring in Great Lakes common terns and Forster's terns, suggesting possible involvement of additional compounds in nature. However, differences between our laboratory studies and field observations may be due to other factors as well that occur in the field. These include the fact that embryo exposure starts at fertilization in nature, parental behavior such as nesting attentiveness can be adversely affected by contaminants such as PCBs [22], and hatchlings receive additional exposure through the remaining yolk and forage that can further reduce growth and survival. All of these factors would intensify preand postfledging mortality from the cumulative effects. Therefore, it is important to be cautious in the interpretation of thresholds from laboratory-derived studies that are not full life cycle.

Acknowledgement-We thank D. Brinker and staff of the Maryland Department of Natural Resources for advice and help in obtaining common tern eggs. We thank T.J. Kubiak and B.A. Rattner for reviewing the manuscript.

\section{REFERENCES}

1. Roberts JR, Rodgers DW, Bailey JR, Rorke MA. 1978. Polychlorinated biphenyls: Biological criteria for an assessment of their effects on environmental quality. 16077. Natural Resources Council, Ottawa, ON, Canada.

2. Safe S. 1984. Polychlorinated biphenyls (PCBs) and polybrominated biphenyls (PBBs): Biochemistry, toxicology, and mechanism of action. CRC Crit Rev Toxicol 13:319-393.

3. Eisler R. 1986. Polychlorinated biphenyl hazards to fish, wildlife, and invertebrates: A synoptic review. US Fish Wildl Serv Biol Rep 85 (1.7).

4. Giesy JP, Ludwig JP, Tillitt DE. 1994. Dioxins, dibenzofurans, PCBs and colonial fish-eating birds. In Schecter A, ed, Dioxins and Health, Plenum, New York, NY, USA, pp 249-307.

5. Rice CP, O'Keefe P. 1995. Sources, pathways and effects of PCBs, dioxins, and dibenzofurans. In Hoffman DJ, Rattner BA, Burton GA Jr, Cairns J Jr, eds, Handbook of Ecotoxicology, Lewis, Boca Raton, FL, USA, pp 424-468.

6. Hoffman DJ, Rice CP, Kubiak TJ. 1996. PCBs and dioxins in birds. In Beyer WN, Heinz GH, Redmon AW, eds, Environmental Contaminants in Wildlife: Interpreting Tissue Concentrations, SETAC, Pensacola, FL, USA, pp 165-207.

7. Kimbrough RD, ed. 1980. Halogenated Biphenyls, Terphenyls, Naphthalenes, Dibenzodioxins and Related Products. Elsevier/ North-Holland, New York, NY, USA.
8. Sawyer T, Safe S. 1982. PCB isomers and congeners: Induction of arylhydrocarbon hydroxylase and ethoxyresorufin $O$-deethylase enzyme activities in rat hepatoma cells. Toxicol Lett 13:5794.

9. Safe S, et al. 1985. Effects of structure on binding to the 2,3,7,8TCDD receptor protein and AHH induction-halogenated biphenyls. Environ Health Perspect 61:21-33.

10. Safe S. 1990. Polychlorinated biphenyls (PCBs), dibenzo-p-dioxins (PCDDs), dibenzofurans (PCDFs), and related compounds: Environmental and mechanistic considerations which support the development of toxic equivalency factors (TEFs). Crit Rev Toxicol 21:51-58.

11. Gilbertson M, Kubiak T, Ludwig J, Fox G. 1991. Great Lakes embryo mortality, edema, and deformities syndrome (GLEMEDS) in colonial fish-eating birds: Similarity to chick-edema disease. J Toxicol Environ Health 33:455-520.

12. Peakall DB, Fox GA, Gilman AD, Hallet DJ, Norstrom RJ. 1980. Reproductive success of herring gulls as an indicator of Great Lakes water quality. In Afhgan BK, MacKay D, eds, Hydrocarbons and Halogenated Hydrocarbons in the Aquatic Environment. Plenum, New York, NY, USA, pp 337-344.

13. Fox GA, Weseloh DV, Kubiak TJ, Erdman TC. 1991. Reproductive outcomes in colonial fish-eating birds: A biomarker for developmental toxicants in Great Lakes food chains. I. Historical and ecotoxicological perspectives. J Gt Lakes Res 17:153-157.

14. Colborn T. 1991. Epidemiology of Great Lakes bald eagles. $J$ Toxicol Environ Health 33:395-454.

15. Kozie KD, Anderson RK. 1991. Productivity, diet, and environmental contaminants in bald eagles nesting near the Wisconsin shoreline of Lake Superior. Arch Environ Contam Toxicol 20: $41-48$.

16. Schwartz TR, Tillitt DE, Feltz KP, Peterman PH. 1993. Determination of mono- and non- $o, o^{\prime}$-chlorine substituted polychlorinated biphenyls in aroclors and environmental samples. Chemosphere 26:1443-1460.

17. Brunstrom B, Andersson L. 1988. Toxicity and 7-ethoxyresorufin $O$-deethylase-inducing potency of coplanar polychlorinated biphenyls (PCBs) in chick embryos. Arch Toxicol 62:263-266.

18. Hoffman DJ, Melancon MJ, Eisemann JD, Klein PN. 1995. Comparative toxicity of planar PCB congeners by egg injection. Proceedings, 2nd SETAC World Congress, Vancouver, BC, Canada, November 5-9, p 207.

19. Best DA, Bowerman WW, Kubiak TJ, Winterstein SR, Postupalsky S, Shieldcastle M, Giesy JP. 1994. Reproductive impairment of bald eagles along the Great Lakes shorelines of Michigan and Ohio. In Meyburg MJ, Chancellor RD, eds, Raptor Conservation Today. World Working Group on Birds of Prey and Pica, East Sussex, UK, pp 697-702.

20. Bowerman WW IV, Giesy JP Jr, Best DA, Kubiak TJ, Sikarskie JG. 1994. The influence of environmental contaminants on bald eagle (Haliaeetus leucocephalus) populations in the Laurentian Great Lakes, North America. In Meyburg BJ, Chancellor RD, eds, Raptor Conservation Today, World Working Group on Birds of Prey and Pica, East Sussex, UK, pp 703-707.

21. Welch LJ. 1994. Contaminant burdens and reproductive rates of bald eagles breeding in Maine. Master's thesis. University of Maine, Orono, ME, USA.

22. Kubiak TJ, et al. 1989. Microcontaminants and reproductive impairment of the Forster's tern on Green Bay, Lake Michigan1983. Arch Environ Contam Toxicol 18:706-727.

23. Brunstrom B, Andersson L, Nikolaidis E, Dencker L. 1990. Nonortho- and mono-ortho-chlorine-substituted polychlorinated biphenyls-Embryotoxicity and inhibition of lymphocyte development. Chemosphere 20:1125-1128.

24. Smith LM, Schwartz TR, Feltz K, Kubiak TJ. 1990. Determination and occurrence of AHH-active polychlorinated biphenyls, 2,3,7,8-tetrachloro- $p$-dioxin and 2,3,7,8-tetrachlorodibenzofuran in Lake Michigan sediment and biota. The question of their relative toxicological significance. Chemosphere 21:1063-1085.

25. Hoffman DJ, Rattner BA, Sileo L, Docherty D, Kubiak TJ. 1987. Embryotoxicity, teratogenicity and aryl hydrocarbon hydroxylase activity in Forster's terns on Green Bay, Lake Michigan. Environ Res 42:176-184

26. Brunstrom B. 1988. Sensitivity of embryos from duck, goose, herring gull, and various chicken breeds to $3,3^{\prime}, 4,4^{\prime}$-tetrachlorobiphenyl. Poult Sci 67:52-57. 
27. Brunstrom B. 1989. Toxicity of coplanar polychlorinated biphenyls in avian embryos. Chemosphere 19:765-768.

28. Brunstrom B. 1990. Mono-ortho-chlorinated chlorobiphenyls: Toxicity and induction of 7-ethoxyresorufin- $O$-deethylase (EROD) activity in chick embryos. Arch Toxicol 64:188-192.

29. Karnofsky DA. 1965. The chick embryo in drug screening: Survey of teratological effects observed in the 4-day chick embryo. In Wilson JG, Warkany JK, eds, Teratology: Principles and Techniques, University of Chicago, Chicago, IL, USA, pp 194-213.

30. Lowry OH, Rosebrough NJ, Farr AL, Randall RJ. 1951. Protein measurements with folin phenol reagent. J Biol Chem 193:265275.

31. Burke MD, Mayer RT. 1974. Ethoxyresorufin: Direct fluorimetric assay of a microsomal $O$-dealkylation which is preferentially inducible by 3-methylcholanthrene. Drug Metab Dispos 2:583-588.

32. Burke MD, Mayer RT. 1983. Differential effects of phenobarbitone and 3-methylcholanthrene induction on the hepatic microsomal metabolism and cytochrome P-450-binding of phenoxazone and a homologous series of its $n$-alkyl ethers (alkoxyresorufins). Chem-Biol Interact 45:243-258.

33. Burke MD, Prough RA, Mayer RT. 1977. Characteristics of a microsomal cytochrome P-448-mediated reaction. Drug Metab Dispos 5:1-8.

34. Burke MD, Thompson S, Elcombe CR, Halpert J, Haaparanta T, Mayer RT. 1985. Ethoxy-, pentoxy- and benzyloxyphenoxazones and homologues: A series of substrates to distinguish between different induced cytochromes P-450. Biochem Pharmacol 34: $3337-3345$

35. Melancon MJ. 1996. Development of cytochromes P450 in avian species as a biomarker for environmental contaminant exposure and effect: Procedures and baseline values. In Bengston DA, Henshel DS, eds, Environmental Toxicology and Risk Assessment: Biomarkers and Risk Assessment, Vol 5. STP 1306. American Society for Testing and Materials, Philadelphia, PA, pp 95-108.

36. Tietze F. 1969. Enzymic method for quantitative determination of nanogram amounts of total and oxidized glutathione. Anal Biochem 27:502-522.

37. Sedlak J, Lindsay RH. 1968. Estimate of total, protein-bound, and nonprotein sulfhydryl groups in tissue with Ellmans's reagent. Anal Biochem 25:192-205.

38. Aust SD. 1985. Lipid peroxidation. In Greenwald RA, ed, Handbook of Methods for Oxygen Radical Research, CRC, Boca Raton, FL, USA, pp 203-207.

39. Brunstrom B, Danerud PO. 1983. Toxicity and distribution in chick embryos of $3,3^{\prime}, 4,4^{\prime}$-tetrachlorbiphenyl injected into the eggs. Toxicology 27:103-110.

40. Powell DC, Aulerich RJ, Stromborg KL, Bursian SJ. 1996. The

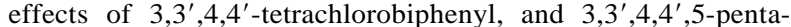
chlorobiphenyl on the developing chicken embryo when injected prior to incubation. $J$ Toxicol Environ Health 49:319-338.

41. Powell DC, Aulerich RJ, Meadows JC, Tillitt DE, Giesy JP, Stromborg KL, Bursian SJ. 1996. Effects of 3,3',4,4',5-pentachlorobiphenyl (PCB 126) and 2,3,7,8-tetrachlorodibenzo-p-dioxin (TCDD) injected into the yolks of chicken (Gallus domesticus) eggs prior to incubation. Arch Environ Contam Toxicol 31:404-409.

42. Rifkind AB, Sassa S, Reyes J, Muschick H. 1985. Polychlorinated aromatic hydrocarbon lethality, mixed-function oxidase induction, and uroporphyrinogen decarboxylase inhibition in the chick embryo: Dissociation of dose-response relationships. Toxicol Appl Pharmacol 78:268-279.

43. Brunstrom B, Reutergardh L. 1986. Differences in sensitivity of some avian species to the embryotoxicity of a PCB, 3, $3^{\prime}, 4,4^{\prime}$ tetrachlorobiphenyl, injected into the eggs. Environ Pollut 42: 37-45.

44. Brunstrom B, Lund J. 1988. Differences between chick and turkey embryos in sensitivity to $3,3^{\prime}, 4,4^{\prime}$-tetrachlorobiphenyl and in concentration/affinity of the hepatic receptor for 2,3,7,8-tetra-chlorodibenzo-p-dioxin. Comp Biochem Physiol C 91:507-512.

45. Hoffman DJ, Smith GJ, Rattner BA. 1993. Biomarkers of contaminant exposure in common terns and black-crowned night herons in the Great Lakes. Environ Toxicol Chem 12:1095-1103.

46. Yamashita N, Tanabe S, Ludwig JP, Kurita H, Ludwig ME, Tatsukawa R. 1993. Embryonic abnormalities and organochlorine contamination in double-crested cormorants (Phalacrocorax auritus) and Caspian terns (Hydroprogne caspia) from the upper Great Lakes. Environ Pollut 79:163-173.
47. Ludwig JP, et al. 1993. Caspian tern reproduction in the Saginaw Bay ecosystem following a 100-year flood event. J Gt Lakes Res 19:96-108.

48. Bowerman WW IV, Kubiak TJ, Holt JB Jr, Evans DL, Eckstein RG, Sindelar CR, Best DA, Kozie KD. 1994. Observed abnormalities in mandibles of nestling bald eagles (Haliaeetus leucocephalus). Bull Environ Contam Toxicol 53:450-457.

49. Hoffman DJ, Rattner BA, Bunck CM, Krynitsky A, Ohlendorf HM, Lowe RW. 1986. Association between PCBs and lower embryonic weight in black-crowned night herons in San Francisco Bay. J Toxicol Environ Health 19:383-391.

50. Rattner BA, Melancon MJ, Custer TW, Hothem RL, King KA, LeCaptain LJ, Spann JW. 1993. Biomonitoring environmental contamination with pipping black-crowned night-heron embryos: Induction of cytochrome P450. Environ Toxicol Chem 12:17191732.

51. Andersson L, Nikolaidis E, Brunstrom B, Bergman A, Dencker L. 1991. Effects of polychlorinated biphenyls with Ah receptor affinity on lymphoid development in the thymus and bursa of Fabricius of chick embryos in ovo and in mouse thymus analagen in vitro. Toxicol Appl Pharmacol 107:183-188.

52. Henshel DS, Hehn B, Wagey R, Vo M, Steeves JD. 1997. The relative sensitivity of chicken embryos to yolk or air-cell-injected 2,3,7,8-tetrachlorodibenzo-p-dioxin. Environ Toxicol Chem 16: $725-732$.

53. Verrett MJ. 1976. Investigation of the toxic and teratogenic effects of halogenated dibenzo- $p$-dioxins and dibenzofurans in the developing chicken embryo. Memorandum Report. U.S. Food and Drug Administration, Washington, DC.

54. Bosveld ATC, Gradener J, Murk AJ, Brouwer A, van Kampen M, Evers EHG, van den Berg M. 1995. Effects of PCDDs, PCDFs, and PCBs in common tern (Sterna hirundo) breeding in estuarine and coastal colonies in the Netherlands and Belgium. Environ Toxicol Chem 14:99-115.

55. Murk AJ, Bosveld ATC, Barua A, van den Berg M, Brouwer A. 1994. Effects of polyhalogenated aromatic hydrocarbons (PHAHS) on biochemical parameters in chicks of the common tern (Sterna hirundo). Aquat Toxicol 30:91-115.

56. Kennedy SW, Lorenzen A, Jones SP, Hahn ME, Stegeman JJ. 1996. Cytochrome P4501A induction in avian hepatocyte cultures: A promising approach for predicting the sensitivity of avian species to toxic effects of halogenated aromatic hydrocarbons. Toxicol Appl Pharmacol 141:214-230.

57. White DH, Hoffman DJ. 1995. Effects of polychlorinated dibenzo-p-dioxins and dibenzofurans on nesting wood ducks at Bayou Meto, Arkansas. Environ Health Perspect 103:37-39.

58. Rifkind AB, Firpo A Jr, Alonso DR. 1984. Coordinate induction of cytochrome P-448 mediated mixed function oxidases and histopathologic changes produced acutely in chick embryo liver by polychlorinated biphenyl congeners. Toxicol Appl Pharmacol 72: 343-354.

59. Hoffman DJ, Melancon MJ, Klein PN, Rice CP, Eisemann JD, Hines RK, Spann JW, Pendleton GW. 1996. Developmental toxicity of PCB $126\left(3,3^{\prime}, 4,4^{\prime}, 5\right.$-pentachlorobiphenyl) in nestling American kestrels (Falco sparverius). Fundam Appl Toxicol 34: $188-200$

60. Hoffman DJ, Rice CP, Melancon MJ, Klein PN, Eisemann JD, Hines RK. 1993. Developmental toxicity of planar PCB congeners in nestling American kestrels (Falco sparverius). Abstracts, 14th Annual Meeting, Society of Environmental Toxicology and Chemistry, Houston, TX, USA, November 14-18, p 178.

61. Sewalk C, Brewer G, Hoffman D. 1996. Effects of diquat on development in mallard embryos. Abstracts, 17th Annual Meeting of the Society of Environmental Toxicology and Chemistry, Washington, DC, USA, November 17-21, pp 143-144.

62. Custer TW, Hines RK, Melancon MJ, Hoffman DJ, Wickliffe JK, Bickham JW, Martin JW, Henshel DS. 1996. Contaminant concentration and biomarker response in great blue heron eggs from 10 colonies on the upper Mississippi river, USA. Environ Toxicol Chem 16:260-271.

63. Tarhanen J, Koistinen J, Paasivirta J, Vourinen PJ, Koivusaari J, Nuuga I, Kannan N, Tatsukawa R. 1989. Toxic significance of planar aromatic compounds in Baltic ecosystem-New studies on extremely toxic coplanar PCBs. Chemosphere 18:1067-1077.

64. Helander B, Olsson M, Reutergardh L. 1982. Residue levels of organochlorine and mercury compounds in unhatched eggs and 
the relationships to breeding success in white-tailed sea eagles Haliaeetus albicilla in Sweden. Holarct Ecol 5:349-366.

65. Struger J, Weseloh DV. 1985. Great Lakes Caspian terns: Egg contaminants and biological implications. Color Waterbirds 8: $142-149$.
66. Mora MA, Auman HJ, Ludwig JP, Giesy JP, Verbrugge DA, Ludwig ME. 1993. Polychlorinated biphenyls and chlorinated insecticides in plasma of caspian terns: Relationships with age, productivity, and colony site tenacity in the Great Lakes. Arch Environ Contam Toxicol 24:320-331. 